\title{
DEVELOPMENT OF CRITICAL-PROCESS SKILLS INTEGRATED ASSESSMENT ON ELECTROLYTE SOLUTION SUBJECT IN SENIOR HIGH SCHOOL
}

\author{
Sri Rejeki Dwi Astuti, Anggi Ristiyana P.S, Siwi Nugraheni, Irwanto, Hesty \\ Sukmasari \\ Department of Chemistry Education, Graduate School \\ Universitas Negeri Yogyakarta \\ srirejeki.dwiastuti@yahoo.com
}

\begin{abstract}
The aim of this paper is to investigate the importance of integrated assessment to measure critical thinking skills and science process skills in chemistry learning. Integrated assessment is an assessment form that integrates several aspects or multidisciplinary science in the assessment process. This integrated assessment is chosen because both have a relationship that can't be separated. Critical thinking skills is part of high order thinking skills that is being education's demand in $21^{\text {st }}$ century. It covers cognitive and skill aspects to construct cognitive component. Science process skills is skill that necessary for students to find their own knowledge by finding or identifying problem, solving problem, and answering questions about natural phenomena, so students' knowledge becomes more meaningful. Process skills are not only intended for science, but also social science that requires critical thinking skills. Therefore, integrated assessment is needed to anticipate the lossing of relationship between critical thinking and science process skills. However, in reality there are many obstacles in measuring both aspects. These problems become the main reason to design integrated assessment that consists of essay which can measure critical thinking and science process skills. The integrated assessment product for electrolyte solution material can be used as alternative instrument to measure critical thinking and science process skills for chemistry educators.
\end{abstract}

Keywords: integrated assessment, critical thinking skills, science process skills

\section{INTRODUCTION}

Assessment is evaluation process to determine the quality and success of learning that includes cognitive, affective and psychomotor aspect. These aspects are very important in chemistry learning. The statement is based on the nature of chemistry as product and chemistry as a process. According to the nature of chemistry, learning product consist of declarative knowledge and procedural knowledge. Declarative knowledge is cognitive knowledge of science including fact, principle, concept, law and theory, while procedural knowledge is knowledge oriented process skills, in other words it called science experience (Ismail \& Jusoh, 2001; Marzano, 2007: 59). Therefore, chemistry learning not only promote cognitive aspect, but also should be balanced 
between cognitive and science process skills.

In the $21^{\text {th }}$ century, student are required to have competence to meet global demand which is known as global competence (Mansilla \& Jackson, 2011: xiii). Global competence includes three aspect such as empirical based knowledge and skills; highorder cognitive and metacognitive skills; and global disposition, prespectives and attitudes (Balistreri et al,2012: 5). The three aspect are reflection of the cognitive, affective and psychomotor which is learning product. Therefore, if the development of three aspect are properly addressed, student will have a good global competence anyway.

One way to prepare the student have a global competence is to prepare student'sognitive aspect, especially aspects of high order thinking skills and metacognitive skills(Balistreri et al, 2012: 5). High order thinking skills in global competence includes critical thinking skills, creative thinking skills and problem solving skills (Brookhart, 2010: 3 ; Moore \& Stanley, 2010: 7; Balistreri et al, 2012: 5). Critical thinking skills is very important for students, because critical thinking are one of the goals of eduation, essential thinking skills in learning process, and as way for selflearning (Judge, Jones, \& McCreery, 2009: 4; (Mahapoonyanont et al., 2010). In chemistry learning, critical thinking emphasizes students to express arguments critically and generate reason that can be accounted. Students who have good critical thinking skills will use reason and reliable fact to support his arguments. So, student should be familiarized use critical thinking skills in learning.

Psychomotor is one of aspect in global competence, that is empirical based knowledge and skills. According to Balistreri (2012: 11), empirical based knowledge and skills are a set of skills and empirical knowledge which is acquired practically. One of skills in empirical based knowledge and skills is science process skills. Science process skills is the things that scientists do when they study and investigate (Rezba et al., 2006: $\mathrm{xv}$ ). Science process skill is very important step in learning process to acquire knowledge and is one of science learning object to prepare student in accumulating knowledge and find their own knowledge (Rauf et al. 2013; Mutisya, Too \& Rotich, 2014). Process skills can be trusted to ensure that student have meaningful knowledge because process skills can help students to improve high order thinking skills. Therefore, development of process skills for student is very important to be noted.

Assessment of learning outcome is still focused in cognitive aspect, whereas the assessment of learning outcome such cognitive and skills must be assessed simultaneously (Zoller, 2001). According to Austin et al. (2015), student who have a good science process skills will have better cognitive abilities than student who don't have the 
skills and rely on memorization. So, we can conclude that there is a relationship between cognitive abilities and science process skills.

In fact, the assessment of cognitive and skills performed separately. If the assessment carried out separately, it will not be obtained the relationship between cognitive and skills aspect, especially the relationship between critical thinking skills and science process skills. These problems become the main reason to design integrated assessment to measure critical thinking skills and science process skills. Therefore, the aim of this paper is to investigate the importance of integrated assessment to measure critical thinking skills and science process skills especially in electrolyte solution subject.

\section{DISCUSSION}

\section{Critical Thinking Skills}

Critical thinking skills is one of high order thinking skills. Various terms have been used to describe these critical thinking skills. Norris \& Ennis (Brookhart, 2010: 4) claim "critical thinking is reasonable, refelctive thinking that is focused on deciding what to believe or do". Moreover, Cottrel (2005: 1) claims that critical thinking is cognitive activity associated with using mental process including attention, catagorization, selection and judgment. Watson \& Glaser (Arsal, 2015) argue that critical thinking is combination of attitudes, knowledge and skills. Based on these definitions, critical thinking is comprehensive and reasonable thinking process toward knowledge which reflected on the resulting arguments and decision .

Arslan (2015) state that critical thinking consists of four component, that are content knowledge (disciplinary field), procedural knowledge (thinking ability), observation skills, as well as controlling and thinking ability. Based on these explanation, critical thinking is an ability that cover cognitive and skills aspect to arrange cognitive component.

Zoller (2001) state that main goal of future education is the development critical thinking skills in specific context and process in chemistry, moreover the relationship with science, technology, environment and society. Based on these explanation, student may be prepared with critical thinking skills to face the competition in the future.

\section{Science Process Skills}

Science process skills is one of soft skills. There are various definition of science procees skills. Different people define and study the science process skills in different ways, so there are many definition of science process skills. Harlen \& 
Huppert et al. (Aktamis \& Ergin, 2008) claim that science process skills is a tool to produce and use scientific information in scientific research and to solve a problem. Student can acquire it by science learning activity. Furthermore, Karsili \& Sahin (Mutisya, Too, \& Rotich, 2014) argue that process skills is skills are used by scientists to discover scientific knowledge, solve problem and make conclusion about the problem. Based on these explanantion, science process skills is skill that necessary for students to find their own knowledge by finding or identifying problem, solving problem, and answering questions about natural phenomena, so students' knowledge becomes more meaningful. Process skills are not only intended for science, but also social science that requires critical thinking skills. So, critical thinking skills assosiated with science process skills.

Padila (Keil, Haney, \& Zoffel, 2012) argue that science process skills consist of two level, that is basic science process skills and integrated process skills. Basic science process skills is foundation skills of scientific method. It consist of six process skills, that is observing, communicating, classifying, measuring metrically, inferring and predicting (Rezba et al., 2006: 5). Integrated science process skills is the development of basic science process skills. It consist of ten proses skills, that is identifying variables, constructing a table of data, constructing a graph, describing relationship between variables, acquiring and processing own data, analyzing investigation, constructing hypotheses, defining variables operationally, designing experiments, and experimenting (Rezba et al., 2006: 5).

\section{Electrolyte Solution Subject in Senior High School}

Electrolyte solution is one of chemistry subject in $2^{\text {nd }}$ semester of X grade in senior high school. This subject include electrolyte, nonelectrolyte solution and electrical charge of solution. The reason of choosing this subject is its application have close relation with dailylife because to trained students' critical thinking skills, need to associated learning with dailylife phenomena. Students' critical thinking skills are seen by the argument that used to identify and solve problem.

\section{Integrated Assesssment}

Assessment is final steps in learning process. Assessment is conducted to determine achievement of learning goals. Assessment instrument is a tool to measure learning outcomes. The result of assessment can be used to conclude students' mastery domain (Stecher, 2010: 9).

According to Brookhart (2010: 8), "Student learn by constructing meaning, incorporating new content into their existing mental representation; therefore, 
improving thinking skills should actually improve content knowledge and understanding as we". Understanding of content knowledge underlie assessment of learning outcomes are more inclined on cognitive aspects. Conventional assessing goal only finite to recall of knowledge. It is called factual knowledge. Assessing method are used to measure these goal is multiple-choice, matching and short-answer. McColskey \& O'Sullivan (2000: 4) argue that to measure high order thinking skills, probelm solving skills and critical thinking skills are not enough to use recall such as worksheet, fact-level question and answer, multiple choice dan short answer. LoucksHorsley (McColskey \& O'Sullivan, 2000: 7) claims that test enables students to explore or investigate problem, solve problem, make science as inquiry model, applying knowledge and empirical evidance to understand nature and technology. Therefore, good instrument, not only examine students' understanding and retention of learning material, but also be able to encourage students applying knowledge to find and solve problems.

Critical thinking skills is one of high order thingking skills, so instrument which is used to measure it similar to high order thingking skills' instruments. The differences of it is critical thinking skills more emphasisnon students' reasoning and judging on an issue. The instrument that used to measure science process skills must include indicators of science process skills. Therefore, instrument to measure science process skills should be able to investigate how much student understanding chemistry concept in terms of concept discovery process.

The assessments of critical thinking skills and science process skills can be carried out simultaneously by integrated assessment. Integrated assessment is an assessment form that integrates several aspects or multidisciplinary science in the assessment process. Schineider (Schneider \& Lane, 2005) state “... the use of ideas and methods from many disciplines that remain unintegrated, to approaches that are interdisciplinary, involving the use of an original combination of multidisciplinary ideas or methods integrated in such a way that they allow for explanations or assessments not possible with unintegrated idea". Based on these explanation, assessment of cognitive and skills aspect can be integrated become one assessment. Cognitive and skills aspect are critical thinking skills and science process skills. The reason of choosing critical thinking skills and science process skills are both have a relationship that can't be separated. Therefore, integrated assessment is needed to anticipate the lossing of relationship between critical thinking and science process skills. 


\section{CONCLUSION AND SUGGESTION}

It is important to develop instrument of critical-process skills integrated assessment to measure critical thinking skills and science process skills on electrolyte solution subject, because to anticipate the lossing of relationship between critical thinking and science process skills. Integrated assessment instrument may also develop in other chemistry subject that requires other thinking skills such as high order thinking skills, creative thinking skills, problem solving skills and analytical thinking skills with science process skills.

\section{ACKNOWLEDGMENT}

The article is under guidance of some consultant. Therefore, the author would like to thanks to Prof. Dr. Endang Widjajanti Laksono, F.X., M.S.; Dr. Suyanta, M.Si; Dr. Eli Rohaeti, M.Si; and Dr. rer. nat. Senam for the guidances.

\section{REFERENCES}

Aktamis, H., \& Ergin, O. (2008). The Effect of Scientific Process Skills Education on Student Scientific Creativity/, Scientific Attitudes and Academic Achievements. Asia-Pasific Forum on Science Learning and Theaching , 9 (1), 1-21.

Arsal, Z. (2015). The Effect of Microteaching on the Critical Thinking Disposition of Pre-service Teacher. Australian Journal of Teacher Education , 40 (3), 141-153.

Arslan. (2015). Investigating Predictive Role of Critical Thinking on Metacognition with Structural. The Malaysian Online Journal of Educational Science , 3 (2), 1-10.

Austin, A. C., Ben-Daat, H., Zhu, M., Atkinson, R., Barrows, N., \& Gould, I. R. (2015). Measuring Student Performance in General Organic Chemistry. Chemistry Education Research and Practice , 1 (16), 168-178.

Balistreri, S., Di Giacomo, F., Noisette, I., \& Ptak, T. (2012). Global Education: Connections, Concepts and Careers. USA: College Board.

Brookhart, S. M. (2010). How to Assess High-Order Thinking Skills in Your Classroom. USA: ASCD.

Cottrel, S. (2005). Critical Thinking Skill Developing Effect Analysis and Argument. New York: PALGRAVE MACMILLAN.

Ismail, Z. H., \& Jusoh, I. (2001). Relationship Between Science Process Skills and Logical Thinking Abilities of Malaysian Student. Journal of Science and Mathematics Education in S.E Asia , xxiv (2), 67-77. 
Judge, B., Jones, P., \& McCreery, E. (2009). Critical Thinking Skills for Education Students. Great Britain: Learning Matters Ltd.

Keil, C., Haney, J., \& Zoffel, J. (2012). Improvements in Student Achievement and Science Process Skills Using Enviromental Health Science Problem-Based Learning Curicula. Electronic Journal of Science Education , 13 (1), 1-18.

Mahapoonyanont, N., Krahomwong, R., Kochakornjarupong, D., \& Raschasong, W. (2010). Critical Thinking Abilities Assessment Tools: Reliability Generalization. Procedia Social and Behavioral Science, 3 (38), 434-438.

Mansilla, V. B., \& Jackson, A. (2011). Educatioan for Global Competence: Preparing Our Youth to Engage the World. New York: Asia Society.

Marzano, R. J. (2007). The Art of Science Teaching. USA: ASCD.

McColskey, W., \& O'Sullivan, R. (2000). How to Assess Student Performance in Science: Going Beyond Multiple-Choice Test. Greensboro: SERVE.

Moore, B., \& Stanley, T. (2010). Critical Thinking and Formative Assessment. New York: Eye on Education.

Mutisya, S. M., Too, J. K., \& Rotich. (2014). Performance in Science Process Skils: The influence of subject specialization . Asian Journal of Social Science \& Humanities , 179-188.

Rauf, R. A., Rasul, M. S., Mansor, A. N., Othman, Z., \& Lyndon, N. (2013). Inculcation of Science Process Skills in Science Classrom. Asian Social Science, 9 (8), 47-57.

Rezba, R. J., Sprague, C. R., McDonnough, J. T., \& Matkins, J. (2006). Learning \& Assessing Science Process Skills. Iowa: Kendall/ Hunt Publishing Company.

Schneider, S., \& Lane, J. (2005). Integrated Assessment Modeling for Global Climate Change: Much Has Beeb Learned-Still a Long and Bumpy Road Ahead. The Integrated Assessment Journal , 5 (1), 41-75.

Stecher, B. (2010). Performance Assessment in an Era of Standard-Based Educational Accountability. Stanford, Ca: SCOPE.

Zoller, U. (2001). AlternativeAssessment as (Critical) Means of Facilitating HOCSPromoting Teaching and Learning in Chemistry Education. Chemistry Education RResearch and Practice in Europe , 2 (1), 9-17. 